\title{
ESPETÁCULO E VIOLAÇÃO DOS DIREITOS DAS CRIANÇAS NA PUBLICIDADE: uma Análise a Partir da Sociedade de Informação
}

\section{Júlia Bagatini}

Professora da FAI Faculdades, mestre e doutoranda em Direito pela Unisc. Advogada. juliabagatini@bol.com.br

\section{Luiz Gonzaga Silva Adolfo}

\begin{abstract}
Mestrado (2000) e Doutorado (2006) em Direito pela Unisinos. Professor do curso de Direito e do Programa de Pós-Graduação em Direito (Mestrado) da Unisc. Coordenador e professor do curso de Direito da Ulbra, campus Gravataí. Pós-Doutorando em Direito pela PUCRS, sob orientação do prof. dr. Ingo Wolfang Sarlet. Membro da Associação Portuguesa de Direito Intelectual (APDI), da Associação Brasileira de Direito Autoral (ABDA) e da Comissão Especial de Propriedade Intelectual da Ordem dos Advogados do Brasil (OAB/RS). adolfo@unisc.br
\end{abstract}

\section{Resumo:}

0 artigo tem como tema principal a sociedade do espetáculo inserida na sociedade de informação, estas como bases às publicidades infantis e, a partir disso, a violação dos direitos das crianças. Desta forma, a problemática que impulsiona a pesquisa é que a publicidade voltada ao público infantil foi intensificada pela sociedade de informação, ou seja, é possível responsabilizar a publicidade posta atualmente pelo desejo de compras infantil. Para tanto, discorre-se acerca da sociedade de informação a partir do risco e da sociedade do espetáculo. Após, a análise se dá na relação de consumo e publicidade voltada ao público infantil, para, então, se verificar a possível violação dos direitos das crianças e adolescentes em tal seara. 0 tema mostra-se de suma relevância no momento em que se verifica uma publicidade voltada ao público infantil, assim como pelo risco que é inerente à sociedade de informação. Verifica-se uma intensificação do consumismo infantil a partir das publicidades voltadas a tal público, mas este fato não é o único responsável, pois há o individualismo exacerbado e a pós-modernidade, que fazem com que os responsáveis pelos infantes os deixem mais expostos às práticas publicitárias.

\section{Palavras-chave:}

Criança. Sociedade de informação. Sociedade do espetáculo. Publicidade.

\section{Revista}

\section{DIREITO \& Debate}

Ano XXVI no 48, jul.-dez. 2017 - ISSN 2176-6622 


\section{SPECTACLE AND VIOLATION OF CHILDREN'S RIGHTS ON ADVERTISING: an Analysis From the Information Society}

\section{Abstract:}

The article has as main theme the society of the spectacle inserted in the society of information, these as bases to the infantile publicity and, from this the violation of the rights of the children. In this way, the problem that drives the research is whether it is possible to say that publicity aimed at the children's public was intensified by the information society, that is, if it is possible to blame the publicity currently placed on the desire for children's purchases. To do so, we discuss the information society, based on the risk and the society of the spectacle. Afterwards, the analysis is based on the relationship between consumption and publicity directed at children, and then, to verify the possible violation of the rights of children and adolescents in this field. The issue is of great relevance, given the moment when there is an advertising aimed at children, as well as the risk inherent in the information society. There is an intensification of children's consumerism from advertising aimed at such a public, but this fact is not the only one responsible, there are others, such as exacerbated individualism, postmodernity, which causes those responsible for infants to leave them more Exposed to advertising practices.

\section{Keywords:}

Child. Information society. Society of the spectacle. Advertising.

Recebido em: 5/7/2017

Aceito em: 25/9/2017

\section{Sumário:}

1 Introdução. 2 A sociedade de informação, o risco e a sociedade do espetáculo. 3 A publicidade voltada ao público infantil e a violação da proteção. 4 A sociedade da informação como fomentadora do risco na publicidade voltada ao público infantil. 5 Conclusão. 6 Referências. 


\section{INTRODUÇÃO}

O trabalho tem como tema a sociedade de informaçáo e a violação dos direitos da criança à luz da publicidade massiva. Nesse sentido, questiona-se se a partir da sociedade da informação, calcada no risco e no espetáculo, há um maior fomento às publicidades voltadas ao público infantil e, a partir disso, a violação dos direitos das crianças, que vai de encontro à doutrina da proteção integral.

Para tanto, faz-se a análise da sociedade do risco e da sociedade da informação e do espetáculo como base teórica, para, então, enfrentar a problemática inicialmente posta. Posteriormente verifica-se a publicidade notadamente voltada ao público infantil. Nesta oportunidade, a partir do exame da publicidade voltada ao público infantil, verifica-se se há ou não a violação de direitos da criança, partindo-se da doutrina da proteção integral.

\section{A SOCIEDADE DE INFORMAÇÃO, O RISCO E A SOCIEDADE DO ESPETÁCULO}

Atualmente, está-se diante da chamada pós-modernidade, que tem como características riscos desconhecidos e danos incontroláveis, preponderando incertezas quanto às consequências oriundas do meio científico e tecnológico. Neste sentido, é necessária a análise da sociedade de risco ${ }^{1}$ no momento atual, posto que passa a ser um mecanismo primordial para o estudo da sociedade de informação e do espetáculo como fomentadoras (ou não) da publicidade infantil.

Para tanto, é imperiosa a distinção advinda da sociedade de risco, que apresenta dois conceitos de modernização, divisão esta feita por Ulrich Beck (BECK, 1998): a primeira é entendida como simples, ocorrida no período industrial, e a segunda é considerada reflexiva.

Utiliza-se a ideia da pós-modernidade, em que está inserida como uma sociedade de risco, conforme as obras de Ulrich Beck e Anthony Giddens. 
A simples é vista como o "estágio em que as formas contínuas de progresso técnico-econômico podem se transformar em autodestruição, em que um tipo de modernização destrói outro e o modifica" (MACHADO, 2005, p. 29).

A segunda forma de modernização não veio objetivando se opor ao modelo industrial, tampouco foi um fenômeno político ou econômico buscado; na verdade, nasceu simplesmente do superdesenvolvimento da modernidade industrial, a qual gerou efeitos e ameaças que não puderam ser assimilados pela racionalidade da época (MACHADO, 2005). A modernidade reflexiva é o confronto das bases do paradigma da modernidade com as consequências da modernização.

A modernidade reflexiva mostra-se, segundo Beck (1998), uma verdadeira sociedade de risco, que acaba questionando, ameaçando e, por fim, destruindo a modernidade industrial. Tal destruição não é instantânea, possuindo dois diferentes momentos: o da reflexividade e o da reflexão. A reflexividade refere-se à transição autônoma, indesejada e despercebida do modelo de sociedade industrial para a sociedade de risco. Tal fato ocorre sem qualquer reflexão (BAGATINI; ADOLFO, 2017).

Passado, entretanto, o momento da reflexividade, surge a reflexão; esta sim é a fase em que os feitos dessa passagem são percebidos pelos diversos segmentos, como a política, o poder público e o meio científico.

Assim, a partir do momento em que os riscos são reconhecidos como tais, sejam tecnológicos ou náo, e oriundos da atividade (e decisóes) humana, as tomadas de decisão passam a ser políticas, e trazem, além de leis objetivando o progresso tecnológico, mecanismos de distribuição destes riscos (BAGATINI; ADOLFO, 2017).

A sociedade de risco emergiu sob a égide e proteção da sociedade industrial. Os riscos fugiram ao controle desta sociedade, surgindo outros - sociais, políticos e econômicos -, que hoje desafiam suas próprias instituiçóes.

Desse modo, a sociedade de risco, a qual tem sua origem associada a fenômenos econômicos oriundos de período posterior à metade do século XX, traz consigo sustentáculos discursivos de risco, mas também de medo, porque muitas das ameaças alertadas são invisíveis ou ao menos são "inimigos” formados em sombras (DIAS, 2017, p. 169). 
Nesse sentido, hodiernamente há a percepção de riscos controláveis e incontroláveis. Os incontroláveis advêm da própria ideia de que a modernidade criou mecanismos para dominar a natureza e controlar perigos e riscos, ${ }^{2}$ mas, diante disso, acabou dando causa a outros riscos, que não conseguiram ser controlados (BAGATINI; ADOLFO, 2017).

Assim, a modernidade reduz riscos em certas áreas ou situaçóes, mas, ao mesmo tempo, introduz novos parâmetros deles, que são totalmente desconhecidos, o que traz riscos incontroláveis para aquele momento (GIDDENS, 1991).

Constata-se, perante esses danos incontroláveis, a falha no funcionamento das normas e instituiçóes desenvolvidas na sociedade industrial. Tais danos atingem a burocracia nacional, incluindo o Direito, que outrora legitimara a criaçáo destes riscos (MACHADO, 2005).

Tais riscos são inerentes ao processo de globalização, uma vez que os danos oriundos destes riscos não são um fenômeno delimitado, e todas as descobertas, triunfos e catástrofes afetam todo o planeta e não mais uma ordem local, nem mesmo um tempo específico (BECK, 1998). Ademais, a sociedade de informação mostra-se uma realidade contemporânea em que se está imbuída de riscos, posto que a todo instante vê-se, a partir da internet, imagens pessoais publicadas e captadas pelas mídias sociais tecnológicas.

A sociedade de riscos, assim como a sociedade de informação, constitui uma sociedade de incertezas cuja problemática surge na continuidade dos processos de modernização autônoma, que são cegos e surdos aos seus próprios defeitos e ameaças (GIDDENS, 1991).

O risco é inerente à (pós)modernidade, e o Estado, que financia e apoia o desenvolvimento da ciência e da tecnologia, ainda não oferece à sociedade respostas eficientes a uma série de novas demandas resultantes dessa modernidade. O Estado tem o dever de proteger a pessoa (normalmente consumidor) desses riscos, ainda

${ }^{2}$ No que diz respeito à diferença entre perigo e riscos, utiliza-se a distinção feita por Luhmann, que afirma que o termo risco vincula-se sempre a uma decisão racional, mesmo que se desconheçam as consequências que poderão vir. Perigo, em contrapartida, é o dano hipotético, ou seja, acarretado por uma causa exterior, não sendo possível ter controle sobre ele, nem mesmo evitá-lo (LUHMANN, 1996). 
mais quando se trata de criança ou adolescente. A proteção deve se dar náo somente com regulamentaçóes, como se verifica no Código de Defesa do Consumidor, mas também na efetividade de aplicação das políticas públicas.

A sociedade de informação é, portanto, um instrumento que surge da pós-modernidade. Desta forma, enquanto outrora a cultura mostrava-se por meio da escrita, hoje parece ser uma cultura da multimídia. A mudança mencionada pode ser comparada ao fenômeno ocorrido na Grécia antiga, onde havia a predominância da língua falada, considerando-se que, após duas geraçōes, foi substituída pela cultura escrita (RAUCH, 1998).

Assim, verifica-se o tempo como base para a mudança paradigmática do comportamento da sociedade. Consoante Melucci (1996, p. 7), "Hoje, o tempo se torna uma questáo-chave na mudança social”.

A internet apresenta-se como um símbolo desta atual mudança advinda da sociedade de informação, entretanto mostra-se uma transformação social diversa das já vividas, isto porque as tecnologias experimentadas e revolucionárias para os períodos históricos, a exemplo da televisão, do computador, da máquina a vapor, do tear mecânico, são mecanismos importantíssimos, mas que encerram uma relação unilateral na qual o indivíduo é mero receptor da tecnologia. Já a internet é "um meio de comunicação que permite, pela primeira vez, a comunicação de muitos com muitos, num momento escolhido, em escala global" (CASTELLS, 2003, p. 8).

\begin{abstract}
A informação produzida até então se enquadrava no conceito da unilateralidade, porquanto produzida e passada aos receptores, no que se convencionou apodar de informação de um para todos, justamente pela mínima possibilidade de interação existente entre produtor e receptor de uma determinada mensagem. Nesse processo, o emissor é o exclusivo produtor da informação, como acontece com notícias ou informaçóes produzidas e veiculadas por panfletos, jornais, revistas, livros e até mesmo a televisão. Todos esses meios, portanto, representam o que se chama de mídias clássicas, ou mídias tradicionais, que se contrapóem com o que hoje se reconhece como novas mídias (SOUZA, 2017).
\end{abstract}

Nesse sentido, o que se verifica na sociedade da informação é que os sujeitos passam de meros espectadores para operadores das tecnologias, visando à comunicação com outras pessoas. 
Ocorre que, a partir da internet, há a proliferação de imagens, facilmente acessíveis à toda população, inclusive ao público infantojuvenil. Assim, a internet e a sua facilitação de acesso trazem o desafio da sociedade e do Estado para que tenham uma nova postura ante a facilidade e rapidez da informação. A ideia de globalização aproximou e tornou possível o consumo por meio da tecnologia, independentemente da distância territorial. Segundo Bauman, a globalização é uma ida sem volta, que afeta a todos.

Para alguns, "globalização" é o que se deve fazer para ser feliz; para outros, é a causa da infelicidade. Para todos, porém, "globalização" é o destino irremediável do mundo, um processo irreversível; é também um processo que afeta a todos na mesma medida e da mesma maneira. Todos estão sendo "globalizados" - e isso significa basicamente o mesmo para todos (1999).

Entende-se, no presente estudo, a sociedade da informação como uma nova maneira de comunicar-se, que advém do mundo globalizado e da sociedade de risco e é altamente representada por meio da internet.

Nesse sentido, a partir da globalização dos meios de comunicação, várias formas de interação foram incorporadas, como o correio eletrônico, a proliferação da utilização de TVs a cabo e as redes sociais, a exemplo do Facebook, Instagran, whatsApp e Skype.

A sociedade de risco encontra-se intimamente ligada à sociedade de informação e, também, na sociedade do espetáculo. Ou seja, verifica-se uma necessidade exacerbada de produçáo e surgimento de novos produtos ou serviços estimulados pela sociedade do espetáculo, em que o consumo e a aparição mostram-se princípios fundantes, não se sabendo os riscos dessa nova estrutura valorativa, o que demonstra a vulnerabilidade do cidadáo atual, notadamente da criança e do adolescente.

Partindo-se da ideia de que se está inserido em uma sociedade do espetáculo, em que a informação, muitas vezes, é manipulada pelos meios de comunicação e que o parecer se sobrepóe ao ter e ao ser, assim como a imagem do produto ou serviço é superior a sua utilidade, parece que a escolha sensata de produtos por parte dos cidadãos encontra-se viciada (DEBORD, 1997). 
Assim, "os riscos são cientificados e ao mesmo tempo são comercializados. Se a fome pode ser superada em boa parte do mundo, mas náo nele todo, os riscos se tornam um novo produto, um 'saco sem fundo' (GOMES; MESQUITA, 2017, p. 18).

A necessidade exacerbada de produção e surgimento de novos produtos ou serviços, em que náo se sabe e que não é possível saber os riscos de sua utilização, mostra vulnerabilidade atual, notadamente da criança, que se encontra em fase de desenvolvimento e vive no contexto da sociedade de informaçáo, e que tem como um dos seus canais de manipulação a publicidade.

\section{A PUBLICIDADE VOLTADA AO PÚBLICO INFANTIL E A VIOLAÇÃO DA PROTEÇÃO INTEGRAL}

A cada dia que passa percebe-se com mais clareza a importância da publicidade e não se pode conceber a sociedade pós-moderna de consumo dissociada, longe da publicidade, ou seja, a publicidade é característica da sociedade de informação e do espetáculo, na qual se estampa o risco. No entendimento de Benjamim (2000, p. 259), "não há um dever legal, imposto ao fornecedor, de anunciar seus produtos e serviços". Há, portanto, uma faculdade, liberdade por parte do fornecedor na publicização de seus produtos e serviços. Se, no entanto, a oferta e a apresentação do produto ou do serviço ocorrem, estas devem assegurar as informaçóes corretas, claras, precisas, ostensivas e em língua portuguesa, conforme disciplina do artigo 31 do Código de Defesa do Consumidor (CDC). ${ }^{3}$

Entende-se que se a publicidade não é um dever do fornecedor, mas um direito, o exercício dela é por sua conta e risco, e o controle da publicidade é da alçada do poder público. Nesse sentido, o controle se dá tanto por organismos de autorregulamentaçáo, como o Conselho Nacional de Autorregulamentaçáo Publicitária (Conar), quanto pelo Estado. Para Benjamim (2000, p. 263), “todos os países

3 Art. 31. A oferta e apresentação de produtos ou serviços devem assegurar informaçóes corretas, claras, precisas, ostensivas e em língua portuguesa sobre suas características, qualidades, quantidade, composição, preço, garantia, prazos de validade e origem, entre outros dados, bem como sobre os riscos que apresentam à saúde e segurança dos consumidores (BRASIL, 2017a). 
democráticos do mundo controlam, de uma forma ou de outra, a publicidade. " No caso brasileiro, a própria Constituição Federal faz este controle, consoante artigo 220, parágrafos $3^{\circ}$ e $4^{\circ} .^{4}$

A publicidade 5 tem a finalidade de incentivar os consumidores a adquirir os produtos e serviços produzidos ou postos à disposição pelos fornecedores, além de captar a atençáo do público consumidor, informá-lo e persuadi-lo, promover os produtos e estimulá-los ao consumo. A publicidade tem uma finalidade puramente comercial.

Assim, é também considerada uma atividade comercial que utiliza técnicas criativas de persuasão e convencimento veiculadas nos meios de comunicação de massa, a fim de criar uma demanda no consumidor, satisfazendo-o e desenvolvendo o bem-estar social e econômico.

Diante disso e da regulamentação consumerista, há um princípio primordial da publicidade, que é de que o consumidor a identifique imediatamente. Nenhuma mensagem veiculada por qualquer forma ou meio de comunicação pode se apresentar de modo disfarçado ou oculto, ou seja, o consumidor deve identificá-la de imediato, para poder se posicionar de maneira adequada às múltiplas informaçóes que lhe são endereçadas.

${ }^{4}$ Art. 220. A manifestação do pensamento, a criação, a expressão e a informação, sob qualquer forma, processo ou veículo não sofrerão qualquer restrição, observado o disposto nesta Constituição. $\$ 3^{\circ}$ Compete à lei federal: I - regular as diversóes e espetáculos públicos, cabendo ao Poder Público informar sobre a natureza deles, as faixas etárias a que năo se recomendem, locais e horários em que sua apresentaçáo se mostre inadequada; II - estabelecer os meios legais que garantam à pessoa e à família a possibilidade de se defenderem de programas ou programaçóes de rádio e televisão que contrariem o disposto no art. 221, bem como da propaganda de produtos, práticas e serviços que possam ser nocivos à saúde e ao meio ambiente. $\$ 4^{\circ} \mathrm{A}$ propaganda comercial de tabaco, bebidas alcoólicas, agrotóxicos, medicamentos e terapias estará sujeita a restriçôes legais, nos termos do inciso II do parágrafo anterior, e conterá, sempre que necessário, advertência sobre os malefícios decorrentes de seu uso (BRASIL, 1988).

5 Normalmente se usa o termo publicidade e propaganda como sinônimos, no entanto eles não podem ser confundidos. O Código de Defesa do Consumidor adota publicidade e náo propaganda, pois a publicidade tem um objetivo comercial e a propaganda um fim de convencimento ideológico, religioso, político e social. 
Assim, para que seja possível a análise de que se está diante de uma publicidade, o consumidor para a qual ela é dirigida deve ter ciência disso, isto é, o público que a publicidade tende a atingir deve ter discernimento necessário de que se trata de uma publicidade.

Ocorre que isso não é possível no caso do público infantil, pois, embora esteja inserido na era da globalização, caracterizada por meios de comunicação e imagens que trazem publicidade ao seu redor, estas pessoas, em especial condiçáo de desenvolvimento, muitas vezes (para não se dizer sempre) não compreendem a publicidade como algo mercadológico, mas sim como uma necessidade; logo, não a detectam imediatamente e, se assim o fazem, não conseguem compreender o objetivo da publicidade.

Nesse sentido, os fornecedores não podem fazer publicidade travestida, subliminar, nem mesmo o merchandising camuflado e, ainda, não podem perpetrar publicidade voltada ao público infantil, uma vez que este público náo a entende como tal, e, assim, não há clareza na informação passada.

Diante do documentário "Criança, a alma do negócio", produzido por Marcos Nisti e Maria Farinha Produçóes (2017), mostra-se perceptível o quanto avassalador é a influência da publicidade no público infantil.

No documentário supramencionado (NISTI, 2017) é possível observar a influência da publicidade nas crianças e adolescentes. Assim, a publicidade, quando direcionada a tal geração, obrigatoriamente deve ser produzida com uma carga extra de cuidado e responsabilidade, afinal, como demonstrado no documentário em comento, a capacidade de compreensão infantil é absolutamente frágil, quando não nulo, o que torna a publicidade responsável exclusiva pelo critério de escolha das crianças (FERNANDES; VEIT, 2017).

As publicidades voltadas no público infantil são, atualmente, veiculadas pelas empresas da informação, sendo estas valoradas com prestígio; logo, verifica-se a influência à criança, que compreende aquilo passado pela mídia como certo, sensacional, necessário, e, portanto, requer aos seus responsáveis aqueles produtos ou serviços objeto da publicidade. 
[...] as estratégias utilizadas para ludibriar crianças e adolescentes no mundo digital são diversas e muitas delas se utilizam de artimanhas da comunicação (marketing, mensagens subliminares, propagandas ou simples engodos de publicidade focados para atrair para determinados sites ou redes de pedofilia, por exemplo) para auferir melhores resultados em seus objetivos, levando consequentemente à violação dos direitos das condiçóes de proteção e desenvolvimento de crianças e adolescentes (DIAS, 2017, p. 160).

Ademais, há que se mencionar a perversidade deste tipo de publicidade, considerando que se tem uma desigualdade que por si só já revela a violação de direitos da criança e do adolescente, pois, de um lado, se apresentam profissionais extremamente qualificados e especializados em publicidade, que investigam o desejo infantil, e, de outro, crianças, que acreditam em tudo o que veem e ouvem, notadamente quando dito pelos seus personagens favoritos.

A fim de barrar com tal violação aos direitos da criança e do adolescente quanto à publicidade voltada a eles, existem várias normas jurídicas que visam as suas proteçôes. Ocorre que a adesão e eficácia não é a esperada, até porque não se verifica uma fiscalização eficiente.

Nesse sentido, consulta-se a Resolução n. 163/2014, editada pelo Conselho Nacional dos Direitos da Criança e do Adolescente (Conanda), ${ }^{6}$ que classifica como abusivas todas as formas de "publicidade e comunicação mercadológica destinadas à criança, com a intenção de persuadi-la para o consumo de qualquer produto ou serviço".

Assim, consoante à Resolução, a "comunicação mercadológica" abrange os meios impressos, comerciais televisivos, banners e sites, embalagens, promoçóes, merchadisings, açôes em shows e apresentaçōes e nos pontos de venda. Também é entendido como publicidade infantil a utilização de celebridades e personagens do público infantil, entre outros.

${ }^{6}$ Conanda é um órgão vinculado à Secretaria de Direitos Humanos da Presidência da República (SDH). 
Acima das Resoluçóes se encontra o Estatuto da Criança e do Adolescente (ECA) e o Código de Defesa do Consumidor (CDC). Ambos diplomas dispóem sobre a abusividade quanto à publicidade infantil. O CDC, em seu artigo $37, \$ 2^{\circ}, 7$ considera abusiva e a coloca como ilegal.

No mesmo sentido, o Estatuto da Criança e do Adolescente traz, no artigo $76,{ }^{8}$ que "as emissoras de rádio e televisão somente exibirão, no horário recomendado para o público infanto-juvenil, programas com finalidades educativas, artísticas, culturais e informativas”.

A lei máxima brasileira, ou seja, a Constituição Federal, também dispóe, em seu artigo 227, que

É dever da família, da sociedade e do Estado assegurar à criança, ao adolescente e ao jovem, com absoluta prioridade, o direito à vida, à saúde, à alimentação, à educação, ao lazer, à profissionalização, à cultura, à dignidade, ao respeito, à liberdade e à convivência familiar e comunitária, além de colocá-los a salvo de toda forma de negligência, discriminação, exploração, violência, crueldade e opressão (BRASIL, 1988).

\footnotetext{
7 Art. 37. É proibida toda publicidade enganosa ou abusiva. $\$ 1^{\circ}$. É enganosa qualquer modalidade de informação ou comunicação de caráter publicitário, inteira ou parcialmente falsa, ou por qualquer outro modo, mesmo por omissão, capaz de induzir em erro o consumidor a respeito da natureza, características, qualidade, quantidade, propriedades, origem, preço e quaisquer outros dados sobre produtos e serviços. $\$ 2^{\circ}$. É abusiva, dentre outras, a publicidade discriminatória de qualquer natureza, que incite a violência, explore o medo ou a superstição, se aproveita da deficiência de julgamento e experiência da criança, desrespeite valores ambientais, ou que seja capaz de induzir o consumidor a se comportar de forma prejudicial ou perigosa à sua saúde ou segurança. $\$ 3^{\circ}$. Para os efeitos deste código, a publicidade é enganosa por omissão quando deixa de informar sobre dado essencial do produto ou serviço (BRASIL, 2017a).

8 Art. 76. As emissoras de rádio e televisão somente exibirão, no horário recomendado para o público infanto juvenil, programas com finalidades educativas, artísticas, culturais e informativas. Parágrafo único. Nenhum espetáculo será apresentado ou anunciado sem aviso de sua classificação, antes de sua transmissão, apresentação ou exibição (BRASIL, 2017b).
} 
Logo, está-se ante a uma legislação garantista, entretanto desrespeitada continuamente, o que traz reflexos graves no desenvolvimento da criança, como, por exemplo, a crescente problemática da obesidade infantil, ${ }^{9}$ a sexualização infantil e a objetização da criança no mercado, a qual é vista como consumidor.

Assim, como mencionado no documentário "Criança, a alma do negócio" (NISTI, 2017), o consumo infantil acompanha os avanços tecnológicos e a sociedade da informação, que é do espetáculo, e o público deseja telefones celulares, tablets, mesmo que não sirvam para nada. Inclusive, é mencionado no documentário que uma adolescente de 14 anos já obteve, em toda sua vida, 9 aparelhos celulares.

No mesmo trilho, verifica-se uma pesquisa do IBGE:

O IBGE em estudo realizado no ano de 2005, levantou dados que demonstram que o consumo de tecnologia por crianças de 10 a 14 anos, principalmente telefonia móvel, hoje soma 5,9\% do mercado, o equivalente a 3.312.157 usuários nesta faixa etária (FERNANDES; VEIT, 2017, p. 1).

Verifica-se, então, que a publicidade voltada ao público infantil é violadora de vários direitos das crianças, em especial os princípios básicos da teoria da proteção integral, que dá base ao Estatuto da Criança e do Adolescente.

Ademais, nota-se, a partir do mencionado, que tal violação se mostra crescente a partir da sociedade de informação, que desperta publicidades de mais fácil acesso ao público infantil.

Nesse sentido, há de se destacar que a publicidade infantil viola a base da Constituição Federal e do Estatuto da Criança e do Adolescente, entre outras normas jurídicas, quando desrespeita o fundamento do ordenamento jurídico, que é a proteçáo integral da criança e do adolescente.

9 Em uma pesquisa do DataFolha/2010, por exemplo, 85\% dos pais afirmaram que a publicidade de alimentos influencia nos pedidos dos filhos. Já no Interscience/2003, 73\% das crianças relataram que as propagandas [publicidade] são responsáveis pelas suas escolhas alimentares. De acordo com a Associação Dietética Norte Americana, são necessários apenas 30 segundos para que uma marca alimentícia influencie uma criança (FERNANDES; VEIT, 2017). 
A teoria jurídica da proteção integral surge num ambiente de busca por democracia, no qual se busca novos modelos alternativos aos impostos pelo antigo regime. A Teoria/Doutrina tornou-se base fundamental do novo Direito da Criança e do Adolescente, surgindo como contraposição absoluta à doutrina da situação irregular, criando a necessidade de um reordenamento institucional - desjudicialização, mudanças de conteúdos, métodos, gestão, dentre outros (CUSTÓDIO, 2017).

Assim, a doutrina da proteção integral traz a absoluta prioridade da criança e do adolescente, conforme dispóe o artigo $1^{\circ}$ do ECA: "Art. 10 Esta Lei dispóe sobre a proteção integral à criança e ao adolescente." Ademais, está amparada constitucionalmente (artigo 227, CF) e consolidada no ECA.

Crianças e adolescentes são, a partir desta teoria basilar, sujeitos de direitos de uma proteção integral, pois lhe são reconhecidos todos os direitos inerentes à pessoa humana. Assim, faz-se necessário promover o reordenamento institucional orientando as açóes voltadas às crianças e aos adolescentes a fim de garantir seus direitos humanos e fundamentais, fomentando a cidadania, a democracia e a transformação social e política tão desejadas por meio de um novo papel pedagógico para a educação: o da proteção integral (CUSTÓDIO, 2017).

É nesse sentido que a publicidade infantil deve ser banida do sistema, ou, entấo, assentada em severas regulamentaçóes e fiscalizaçóes, o que pouco se verifica hodiernamente.

Observa-se, então, que a teoria da proteção integral da criança e do adolescente é um pressuposto de compreensão do direito destes no Brasil contemporâneo, esta entendida como uma disciplina autônoma a partir da Constituição Federal de 1988.

\section{A SOCIEDADE DA INFORMAÇÃO COMO FOMENTADORA DO RISCO NA PUBLICIDADE VOLTADA AO PÚBLICO INFANTIL}

Nas últimas décadas é possível observar uma evolução no desenvolvimento de produtos e publicidades voltados para o público infantil. Isso decorre do fato de que as empresas perceberam que as crianças eram consumidoras inexploradas, e devia-se voltar-se o mercado também a elas. 
Bustelo (2011, p. 61), inclusive, em sua obra El recreo de la infancia: argumentos para outro comienzo, traz importantes reflexôes no que diz respeito à relação infância/consumidores, e esta influência de biopoder do marketing e das grandes empresas nas crianças e adolescentes, referindo-se acerca da comunicação massiva, que hoje se dá por meio de videogames, televisão, shoppings e parques temáticos. As crianças são educadas para se incorporar rapidamente ao consumo.

O momento histórico para tratar da criança como consumidora foi propenso, posto que os pais ou responsáveis encontram-se cada vez mais sem tempo para seus filhos e, para que seja possível a realização de suas tarefas diárias, recorrem à sociedade de informaçáo, especialmente à televisão, que deixa, por longas horas a fio, a criança encantada.

A publicidade voltada a tal público se encontra justamente nas mídias que os pais apresentam a seus filhos; logo, vê-se propício ao mercado a publicidade direcionada ao público infantil.

A publicidade brasileira se voltou para o público infantil nas décadas de 70 e 80 do século 20, crescendo drasticamente nos últimos anos. Nos anos 80 utilizava-se de açôes publicitárias para a sedução das crianças, surgindo programas especificamente para o público infantil, como "Topo Gigio", "Vila Sésamo" e "Xou da Xuxa” (SOUZA JÚNIOR; GAZAL; MACIEL, 2009).

Foi nesse contexto que se iniciou a ideia de mercantilização infantil por meio das publicidades, sendo a criança alvo da mídia e do marketing. Sampaio menciona (2009):

O processo de intensificação do acesso das crianças às mídias vem seguindo, lamentavelmente, a lógica da comercialização da infância. A descoberta de que as crianças e os adolescentes constituem mundialmente um mercado rentável tem ocasionado o desenvolvimento do marketing infantil e a intensificação da publicidade dirigida a este segmento (p. 13).

Shimp (2009, p. 80) assim se refere: "segundo uma estimativa, as empresas norteamericanas gastaram recentemente 15 bilhôes de dólares na publicidade e marketing de suas marcas para as crianças até 12 anos". 
Perante o mundo globalizado, a publicidade infantil tem aumentado significativa e gradualmente, e a criança passa a ser tratada como potencial consumidor, inclusive há apelos em desenhos e filmes infantis mais acessíveis ao público pela facilidade advinda da sociedade de informação, fomentada pela sociedade do espetáculo.

Nesse sentido, verifica-se a dificuldade de controle das publicidades infantis neste mundo globalizado, posto que:

As crianças assistem em média 3,5 horas por dia de televisão, sendo cerca de 40 minutos de propagandas [publicidades], geralmente dirigidas a elas próprias. O apelo da mídia muitas vezes utiliza as próprias crianças como protagonistas dessas propagandas, como um mecanismo de identificação e apelo emocional. A televisão é uma das principais influenciadoras no âmbito da formação social dos indivíduos, sendo uma das responsáveis pela redução do distanciamento entre a infância e a idade adulta, estando presente em mais de $91 \%$ dos domicílios brasileiros (SOUZA JÚNIOR; FORTALEZA; MACIEL, 2017 apud JUNQUEIRA et al., 2017).

Sampaio (2009) reforça ainda que a publicidade televisiva tem grande influência sobre o público infantil, transformando as crianças em consumidores, uma vez que as grades de programação da televisão fazem dos programas verdadeiras vitrines de produtos. $\mathrm{O}$ vínculo entre os programas e os produtos se tornou tão estreito que as crianças são estimuladas a conviver com as marcas, os produtos, os personagens e os apresentadores, que se misturam ao seu cotidiano por meio das políticas de licenciamento, estando presentes em suas refeiçôes, na escola, no vestuário e no lazer.

As crianças acabam sendo potenciais consumidoras não necessariamente por serem consumidoras diretas, mas porque são catalisadoras de consumo de terceiros, ou seja, influenciam na decisão de compra dos seus pais.

Segundo Linn (2006 apud SANTOS; GROSSI, 2009, p. 448), “o consumo infantil fatura cerca de US\$ 15 bilhôes por ano e o poder de persuasão das crianças nas compras dos adultos aproxima-se de US\$ 600 bilhôes". 
O fato é que a sociedade de informação, calcada na sociedade do espetáculo, que traz o parecer sobrepondo-se ao ser e ao ter, revela a necessidade de consumo e de produção de bens cada vez maior (DEBORD, 1997), fato que é estimulado ao público infantil, que, por ter menor consciência e percepção publicitária, mostra-se ideal ao consumo.

Embora o acesso às mídias, televisão, outdoors, smartphones sejam reais e cada vez maiores no público infantil, de outro lado, como já referido, se verifica famílias cada vez mais individualistas, que acabam por reforçar a tendência do mercado ao público infantil, pois se percebe um distanciamento nas famílias em que não há o acompanhamento real das crianças, o que faz com que elas se influenciem pelo sistema consumerista (JUNQUEIRA et al., 2017).

Desta forma, observa-se que a publicidade, notadamente a voltada ao público infantil, alimenta o estado da necessidade de a sociedade consumir, e este processo é potencializado a partir do aparecimento da sociedade de informação e das novas constituiçóes familiares, na qual crianças passam a ter mais acesso às publicidades voltadas para elas.

Há de se destacar alguns dados do Instituto Alana, citados no relatório anual, que trata de marcas que foram notificadas acerca da publicidade voltada ao público infantil.

No ano passado, a Pespsico do Brasil foi autuada pelo Procon e multada em R \$ 1.413.986,67 por veicular a campanha "Invasão Angry Birds", em que ao comprar salgadinhos, achocolatados e bolachas da empresa os consumidores poderiam trocar por bonecos de pelúcia. Já a Nestlé precisa pagar R $\$$ 4.610.986,67 por fazer merchandising do produto Chamyto $1+1$ durante a novela infantil Carrossel. As duas marcas foram condenadas em primeira instância (VAZQUEZ, 2017).

Verifica-se, portanto, que a sociedade de informação é fomentadora e instigadora da publicidade do público infantil, entretanto não há que se colocar a nova forma estruturada como única responsável pela criança como consumidor potencial, pois há outras instituiçóes, como família e Estado, silentes a tal apelo publicitário, o que ocasiona a violaçáo de normas jurídicas pelas grandes empresas 
de marketing que trabalham para o público infantil, e também pelos pais e Estado, que acabam por não realizar seus papéis em relação aos princípios e regras da doutrina da proteção integral da criança e do adolescente.

\section{CONCLUSÃO}

A sociedade do risco encontra-se umbilicalmente ligada à sociedade da informação e esta à sociedade do espetáculo, em que as mídias sociais e as novas tecnologias passam a ser protagonistas do atual momento em que estamos inseridos. O parecer sobrepóe-se ao ser e ao ter, considerados outrora como valores primordiais, o que faz com que o mercado use este novo valor imposto e passe a utilizar a proliferação de produtos, em que o que se procura não é a utilidade, mas a aparência.

A partir deste panorama, o mercado voltado ao marketing vê a criança como potencial consumidor e passa à produção de bens e serviços a este público, com o viés da descartabilidade, que é inerente à sociedade do espetáculo.

Ocorre que por ser a criança um ser em desenvolvimento, a publicidade posta pelo mercado não é entendida como tal e acaba persuadindo o infante e, consequentemente, a família, pois se verifica hoje uma maior voz infantil no ambiente familiar a adquirir tudo o que está publicizado.

Desta maneira, as publicidades são mais acessíveis às crianças a partir da pós-modernidade, em que os meios de comunicação foram difundidos. Logo, ante o individualismo exacerbado no âmbito familiar, em que as crianças são, inclusive, estimuladas a ficar em frente à televisão, verifica-se um maior acesso destes infantes a publicidades e, portanto, maior adesão ao marketing, que, consequentemente, traz a violação dos direitos da criança.

Constata-se, portanto, no presente artigo, que parece ser a sociedade de informação um dos mecanismos fomentadores à publicidade voltada ao público infantil, e, com isso, verifica-se o desrrespeito à teoria da proteçáo integral da criança e do adolescente. 
Não há soluçôes prontas para a problemática posta. O ideal seria uma intensificação na educação dos responsáveis pelas crianças para que estas ficassem menos expostas às publicidades advindas da sociedade da informação e do espetáculo, pois estas, por serem a marca da pós-modernidade, mostram-se intensificadoras do mercado voltado ao público infantil.

\section{REFERÊNCIAS}

BAGATINI, Júlia; ADOLFO, Luiz Gonzaga Silva. A responsabilidade civil à luz da solidariedade na sociedade de risco: construindo um direito de danos. Disponível em: <file:///C:/ Users/J\%C3\%BAlia/Downloads/15761-12678-1-PB\%20(2).pdf>. Acesso em 24 jun. 2017. BAUMAN, Zygmunt. Modernidade e ambivalência. Tradução Marcus Penchel. Rio de Janeiro: Zahar, 1999.

BECK, Ulrich. A reinvenção da política: rumo a uma teoria da modernização reflexiva. In: BECK, Ulrich; GIDDENS, Anthony; LASH, Scott. Modernização reflexiva: política, tradiçẫo e estética na ordem social. Tradução Magda Lopes. São Paulo: Unesp, 1998.

BENJAMIN, Antônio Herman de Vasconcellos e. Comentários ao código de proteção do consumidor. Comentadores Toshio Mukai et al. Coordenador Juarez de Oliveira. São Paulo: Saraiva, 2000.

BRASIL. Constituição da República Federativa do Brasil. 1988. Disponível em: <http://www. planalto.gov.br>. Acesso em: 14 jun. 2017.

. Código de Defesa do Consumidor. Disponível em: <http://www.planalto.gov.br>. Acesso em: 14 jun. 2017a.

. Estatuto da Criança e do Adolescente. Disponível em: <http://www.planalto.gov. br>. Acesso em: 14 jun. 2017b.

BUSTELO, Eduardo. El recreo de la infancia: argumentos para outro comienzo. 2. ed. Buenos Aires: Siglo Veintiuno, 2011.

CASTELLS, Manuel. A galáxia da Internet: reflexôes sobre a internet, os negócios e a sociedade. Tradução Maria Luiza Borges. Rio de Janeiro: Zahar, 2003.

CUSTÓDIO, André Viana. Teoria da proteção integral: pressuposto para compreensão do direito da criança e do adolescente. Disponível em: <https://online.unisc.br/seer/index.php/ direito/article/view/657/454>. Acesso em: 19 jun. 2017. 
DEBORD, Guy. A sociedade do espetáculo. Rio de Janeiro: Contraponto, 1997.

DIAS, Felipe da Veiga. O direito fundamental da criança e do adolescente à informação e as políticas públicas de comunicação preventivas e protetivas de conteúdo adulto na internet no Brasil. Disponível em: <http://repositorio.unisc.br/jspui/bitstream/11624/473/1/Felipe\%20 da\%20Veiga\%20Dias.pdf>. Acesso em: 14 jun. 2017.

FERNANDES, André Gonçalves; VEIT, Brisa. Publicidade infantil à luz do CDC. Disponível em: <https://jus.com.br/artigos/48005/publicidade-infantil-a-luz-do-cdc>. Acesso em: 18 jun. 2017.

GIDDENS, Anthony. As consequências da modernidade. São Paulo: Unesp, 1991.

GOMES, Magno Federici; MESQUITA, Leonardo Paiva. Sociedade de risco, sustentabilidade para gestão e princípio da precaução. Disponível em: <https://online.unisc.br/seer/index.php/ direito/article/view/7863/5584>. Acesso em: 21 jun. 2017.

JUNQUEIRA, Fernanda Campos et al. A relação entre o marketing televisivo voltado para o público infantil e a decisão de compra dos pais. Disponível em: <http://www.aedb.br/seget/ arquivos/artigos14/22020185.pdf>. Acesso em: 18 jun. 2017.

LUHMANN, Niklas. Confianza. Barcelona: Anthropos, 1996.

MACHADO, Marta Rodriguez de Assis. Sociedade do risco e Direito Penal. Uma avaliação de novas tendências político-criminais. São Paulo: IBCCRIM, 2005.

MELUCCI, Alberto. Juventude, tempo e movimentos sociais. Trad. Angelina Teixeira Peralva. Revista Young, Estocolmo, v. 4, n. 2, p. 3-14, 1996. Disponível em: <http://proex.pucminas.br/sociedadeinclusiva/Blog:\%20Direito\%20de\%20se \%20Diferente/Juventude,\%20 Tempo\%20e\%20Movimentos\%20Sociais.pdf>. Acesso em: 21 jun. 2017.

NISTI, Marcos. Documentário Criança, a alma do negócio. Disponível em: <https://www. youtube.com/watch?v=KQQrHH4RrNc>. Acesso em: 21 jun. 2017.

RAUCH, Wolf. Ética da informação. O problema sob a ótica da ciência da informação. Trad. Paulo Astor Soethe. In: KOLB, Anton; ESTERBAUER, Reinhold; RUCKENBAUER, Hans-Walter (Org.). Ciberética: responsabilidade em um mundo interligado pela rede digital. São Paulo: Ediçóes Loyola, 1998.

SAMPAIO, Inês Silvia Vitorino. Publicidade e infância: uma relação perigosa. In: VIVARTA, Veet (Coord.). Infância e consumo: estudos no campo da comunicação. Brasília, DF: Andi; Instituto Alana, 2009. 
SANTOS, Andréia Mendes, GROSSI, Patrícia. Infância comprada: hábitos de consumo na sociedade contemporânea, 2009. Disponível em: <http://repositorio.pucrs.br/dspace/ bitstream/10923/8161/2/Infancia_comprada_habitos_de_consumo_na_sociedade_contemporanea.pdf>. Acesso em: 19 jun. 2017.

SOUZA JÚNIOR, José Ednilson Gomes de; GAZAL, Camila Hildebrand Fortaleza; MACIEL, Josemar De Campos. Publicidade infantil: o estímulo à cultura de consumo e outras questôes. Brasília: Instituto Alana, 2009.

SOUZA, Liége Alendes de. As redes sociais virtuais como instrumento de construção do espaço público e persecução da democracia substancial no Brasil: (im)possibilidades contemporâneas. Disponível em: <http://www.unisc.br/portal/images/stories/curso-24/dissertacoes/2014/ liege_alendes_de_souza.pdf>. Acesso em: 20 jun. 2017.

SHIMP, Terence A. Comunicação integrada de marketing: propaganda e promoção. 7. ed. Porto Alegre: Bookman, 2009.

VAZQUEZ, Rafael. Grandes marcas são denunciadas por publicidade infantil abusiva. Disponível em: <http://propmark.com.br/mercado/grandes-marcas-sao-denunciadas-por-publicidade-infantil-abusiva>. Acesso em: 18 jun. 2017. 